Michelle

$\mathrm{B} / 130218075$

\title{
SUSTAINABILITY OF LOBSTER IN INDONESIA
}

As an archipelagic and maritime country, Indonesia has attracted many fishermen from all over the world due to its abundance of marine resources. The government's policy to open lobster seed exports and legalize fishing equipment that was previously prohibited (shrimp trawl, payang, cantrang) in the Minister of Marine Affairs and Fisheries Regulation Number 12 of 2020 has created many debates (Tayibnapis et al., 2020).

The policy that allows the export of lobster seeds, according to the Ombudsman of the Republic of Indonesia, violates the economic constitution mandated in Article 33 of the 1945 Constitution which states that lobster seeds are an extractive natural resource that is mostly obtained from hatcheries. As a result, the use of lobsters for export must be handled by the government transparently. Moreover, the policy has also caused horizontal conflicts between fishermen. Fishermen have often clashed in the past about the use of non-environmentally friendly fishing equipment. Crab fishing boats, for example, are often struck by boats armed with arad nets (cantrang variant), resulting in crab net destruction (Tayibnapis et al., 2020).

Given the limited state income, the program on lobster seed export seems to be less profitable and has the potential to cause huge lobster seed exploitation, endangering the ecosystem's equilibrium. In reality, the export of lobster seeds would only help Vietnam's lobster expansion industry because of the large disparity in the price of lobster seeds at the fishermen level and the export market.

\begin{tabular}{|c|c|c|}
\hline \multirow{2}{*}{ Destination } & \multicolumn{2}{|c|}{ Fourth Quarter of 2019 } \\
\cline { 2 - 3 } & Living (head) & $\begin{array}{c}\text { Non-living } \\
\text { (head) }\end{array}$ \\
\hline China & $1,276,785$ & 36,207 \\
\hline Timor Leste & - & 20 \\
\hline Hong Kong & 260,209 & 25 \\
\hline Japan & - & - \\
\hline South Korea & 346 & 6 \\
\hline Malaysia & 6,201 & 3,056 \\
\hline Singapore & 26,456 & 2,311 \\
\hline Taiwan & 752,450 & 6,865 \\
\hline Thailand & 4,725 & - \\
\hline USA & - & - \\
\hline Vietnam & 166 & - \\
\hline Total & $2,327,338$ & 48,489 \\
\hline
\end{tabular}


Given the limited state income, the program on lobster seed export seems to be less profitable and has the potential to cause huge lobster seed exploitation, endangering the ecosystem's equilibrium. In reality, the export of lobster seeds would only help Vietnam's lobster expansion industry because of the large disparity in the price of lobster seeds at the fishermen level and the export market (Tayibnapis et al., 2020).

Legalization of lobster seed export, according to the Ministry of Marine Affairs and Fisheries, would favor all parties: seed fishermen and cultivators will gain economic value, exporters will profit, the state will gain revenue, lobster smuggling will decrease, and thousands of fishermen who rely on catching lobster seeds will prosper. The amount of cultivated lobster production is expected to reach 303 billion rupiah in 2020, rising to 1.73 trillion rupiah in 2024 . Furthermore, several techniques will be used to improve lobster farming, including the development of an upstream-downstream supply chain system (Tayibnapis et al., 2020).

Logistical issues, a lack of market control, and the difficulties of collecting lobster seeds to cultivate are some of the reasons that make Indonesian lobster exports uncompetitive in the international market. Indonesia's lobster exports are mostly only focused on China, Taiwan, Hong Kong, and Singapore. Many shrimp cultivators complain about the complexity of company licensing legislation, such as the Regional Regulation which states that cultivation ponds including buildings and the fee are calculated per square meter (Tayibnapis et al., 2020).

\begin{tabular}{|c|c|c|c|c|c|}
\hline Year & $\begin{array}{c}\text { Release } \\
\text { Estimates } \\
\mathbf{2 \%} / \mathrm{Kg}\end{array}$ & $\begin{array}{c}\text { Release } \\
\text { Estimates } \\
\mathbf{2 \% / h e a d}\end{array}$ & $\begin{array}{c}\text { Hole of } \\
\text { floating net } \\
\text { cage }(3 \times 3 \mathrm{~m})\end{array}$ & $\begin{array}{c}\text { Need for } \\
\text { seeds (head) }\end{array}$ & $\begin{array}{c}\text { Production } \\
\text { (ton) }\end{array}$ \\
\hline 2020 & 137,700 & 20,655 & 49,175 & $9,835,700$ & 1,377 \\
\hline 2021 & 239,600 & 35,940 & 85,575 & $17,114,300$ & 2,396 \\
\hline 2022 & 420,500 & 63,075 & 150,180 & $30,035,700$ & 4,205 \\
\hline 2023 & 496,500 & 74,475 & 177,325 & $35,464,300$ & 4,965 \\
\hline 2024 & 722,000 & 108,300 & 257,850 & $51,571,500$ & 7,220 \\
\hline
\end{tabular}

In light of the table above, the Minister of Marine Affairs and Fisheries Regulation Number 12 of 2020 should not be implemented in 2020, as it is linked to Government Regulation Number 75 of 2015 concerning Types and Tariffs of Non-Tax State Revenues, which is no longer applicable now or in the future. Furthermore, findings by KomisiNasional KajianSumber Dayalkan in 2018 revealed that lobster resources in 11 fisheries management areas are in the red and yellow zones, indicating that adult lobsters and lobster seeds must be captured with extreme 
caution (Tayibnapis et al., 2020). Lobster collecting practices in all Indonesian WPPs are now at an alarming level; out of 11 WPPs in Indonesia, four are completely exploited, and seven are overexploited (Maskun et al., 2020).

The roadmap for lobster cultivation in Indonesia from 2020 to 2024 seems to be too ambitious and is ignorant to the field conditions. This new policy, for example, has resulted in an unreasonable rise in the price of lobster seeds. It is predicted that if lobster seeds are taken continuously for export purposes for three years, cultivators would no longer be able to procure the seeds in the fourth year. Lobster cultivators' predicament has deteriorated as the price of harvested lobsters has fallen sharply, making it impossible for them to sell them. Farmers are often faced with being unable to pursue their lobster expansion business due to an inability to finance highly costly seeds (Tayibnapis et al., 2020). According to Abdul Halim, Executive Director of the Centre for Maritime Studies for Humanity, this legislation would have three consequences on farmers: (1) Obtaining good quality baby lobster is difficult, (2) obtaining good quality baby lobster at a reasonable price is difficult, and (3) their lobster's sale price will plummet because it won't be able to compete with neighboring countries, especially Vietnam (Maskun et al., 2020).

The government should take strategic measures such as delaying the enforcement of the new strategy, simplifying central and regional licensing, stopping the export of lobster seeds, reducing the likelihood of marine mammal mortality, choosing more environmentally safe lobster fishing gear, and restructuring the relationship pattern so that cultivators and fishers have legal certainty (Tayibnapis et al., 2020). The government should concentrate on raising fishermen's capacity to run a successful lobster farming industry. Furthermore, there is a need to improve the unity among lobster grower business groups so that they can share their experiences and expertise. This is due to the nature of the solitary lobster business in Indonesia, reducing fishermen's and lobster traders' bargaining power (Maskun et al., 2020).

\section{REFERENCES}

Maskun, Ilmar, A., Napang, M., Naswar, Achmad, \& Assidiq, H. (2020). Legal analysis of lobster export policies in Indonesia: The principle of sustainable development approach. IOP Conference Series: Earth and Environmental Science, 564(1). 
https://doi.org/10.1088/1755-1315/564/1/012067

Tayibnapis, A. Z., Wuryaningsih, L. E., \& Gora, R. (2020). International Journal of Multicultural and Multireligious Understanding The Impact of Minister of Marine Affairs and Fisheries Regulation Number 12 of 2020 on the Sustainability of Lobster in Indonesia. $12,130-136$. 